\title{
SPEKTRUM HISTORIS TAFSIR AL-QUR'AN DI INDONESIA
}

\author{
Abd. Latif \\ Fakultas Ushuluddin dan Studi Agama UIN STS Jambi \\ Email: syeikhabdullatif@gmail.com
}

\begin{abstract}
This work examines the historical spectrum of interpretations of the Koran in Indonesia, which begins with a discussion of the socio-cultural context of interpretive studies in Indonesia, which is presented as an opening discussion for understanding the basis or socio-cultural basis of interpretation produced in the archipelago Indonesia. Furthermore, the author writes about the embryonic interpretation in Indonesia which actually has begun along with the spread and growth of Islan in the archipelago. Finally, the author closes the discussion on the development of interpretations in Indonesia which the author frames in three periods, namely the classical, modern, and contemporary periods. The classical period begins from the beginning of the 17 th century until the end of the 19th century; the modern period begins from the first half of the twentieth century to the end of the 1980s, and the contemporary period dates from the early 1990 s to the present.
\end{abstract}

Karya ini menelisik tentang spektrum historis tafsir al-Qur'an yang ada di Indonesia, yang diawali dengan pembahasan tentang konteks sosialbudaya kajian tafsir di Indonesia, yang sajikan sebagai pembahaan pembuka untuk memahami landasan atau basis sosial-budaya tafsir yang dihasilkan di bumi Nusantara Indonesia. Selanjutnya penulis menulis tentang embrio tafsir di Indonesia yang sesunggiuhnya telah dimulai seiring degan peryebaran dan pertumbuhan Islan di Nusantara. Akhirnya penulis menutup pembahasan tentang perkembangan tafsir di Indonesia yang penulis bingkai dalam tiga periodesasi, yaitu periode klasik, modern, dan kontemporer. Periode klasik diawali sejak awal abad ke-17 hingga akhir abad ke19; periode modern diawali sejak peruh pertama atau 
pertengahan abad ke-20 hingga akhir tahun 1980-an, dan periode kontemporer terjadi sejak awal tahun 1990-an hingga sekarang.

Keywords: Tafsir, Klasik, Modern, Situasi Sosial, Ayat Al-Qur'an

\section{Pendahuluan}

Tidak ada yang meragukan bahwa Tafsir al-Qur'an merupakan bagian dari kegiatan ilmiah yang paling utama dan bernilai dalam serangkaian kegiatan ilmiah di dunia Islam. Tafsir al-Qur'an tidak saja menjadi acuan teoritik keilmuan yang demikian luas, namun juga menjadi sendi bagi aktivitas praktis umat Islam di sepanjang masa. Hal ini sejak awal telah menjadi kesadaran dari sejumlah Ulama Islam klasik, yang menjadikan al-Qur'an sebagai sumber utama ajaran Islam, yang khususnya dalam bidang Teologi, Syari'ah dan Moral. Di mana hasil penafsiran dari al-Qur'an kemudian memunculkan berbagai pandangan teologis, figh, dan juga moral yang mengjawantah dalam berbagai aliran teologi, mazhab fiqh, dan juga ajaran moral. ${ }^{1}$

Dalam pemahaman seperti di ataslah kemudian Raghib alIsfahani menyatakan tiga keutamaan tafsir al-Qur'an, yaitu: Pertama, keutamaan dari segi materi, mengingat tafsir al-Qur'an membahas Kalamullab yang menjadi acuan utama atau otoritas tertinggi bagi umat Islam; Kedua, keutamaan dari sudut tujuan, yaitu bahwa tafsir al-Qur'an juga merupakan acuan ataupun rujukan bagi kaum Muslimin dalam mengarungi bahtera kehidupannya di dunia menuju kebahagiaan di akhirat; terakhir, Ketiga, keutamaan dari sisi kebutuhan atau urgensitasnya, bahwa tafsir al-Qur'an merupakan pintu utama dalam menyelami dan memahami kandungan alQur'an, sehingga akan mustahil utuk memahami kandungan isi alQur'an tanpa melalui tafsir al-Qur'an, hanya dengan cara inilah ilmu

${ }^{1}$ Muhammad Iqbal, “Contemporary Development of Qur'anic Exegesis in Indonesia and Iran", Jurnal of Contemporary Islam and Muslim Society, Vol. 3, No. 1 Januari-Juni 2019, 84. 
syari'at dan segenap pengetahuan agama Islam dapat diketahui dan dipahami. ${ }^{2}$

Kenyataan di atas kemudian memberikan kesadaran komunal di tengah umat Islam untuk menyakini bahwa al-Qur'an merupakan kitab suci yang menjadi petunjuk umat manusia, khususnya bagi umat yang beriman dan bertaqwa, kapanpun dan di mana pun mereka berada. ${ }^{3}$ Dengan ungkapan lain bahwa umat Islam telah menempatkan al-Qur'an ke dalam pusat kesadarannya, sehingga tafsir al-Qur'an juga menempati kedudukan yang penting dalam kesadaran dan tradisi keilmuan umat Islam.

Urgensitas tafsir di atas tampaknya bukan hanya menjadi dominasi ulama Islam klasik, namun juga terjadi dalam blantara keilmuan Islam di Indonesia, karena penelusuran terhadap jejak historis tafsir di Indonesia menjadi penting untuk dikemukakan. Dalam konteks demikianlah penulis, tertarik untuk mengemukakan lebih jauh mengenai Sejarah Tafsir khususnya dalam Konteks keIndonesiaan.

Kajian tafsir yang ada di Indonesia telah mengalami perkembangan yang cukup panjang mulai dari periode klasik, periode modern hingga periode kontemporer. Di mana masingmasing tafsir yang memang tidak dalam kesempatan ini didalami satu persatu memiliki kekhasan tersendiri, karena ia lahir dan tumbuh dalam sebuah ruang sosial budaya tertentu, hal inilah yang kemudian turut memberikan corak dan pola terhadap tafsir yang dihasilkan. Walaupun demikian sebuah apresiasi besar tetap harus

${ }^{2}$ Lihat Raghīb al-Isfahānī, dalam Abu al-Fadhl Jalāl al-Dīn al-Suyūtī, al-Itqān fi Ulüm al-Qur'an, (Beirut: Dar al-Kutub al-Ilmiyah, 1991), Vol. 2, Cet. 2, 381-386.

3Surahman Amin dan Ferry Muhammadsyah Siregar, "Telaah atas Karya Tafsir di Indonesia: Studi atas Tafsir al-Bayan Karya TM. Hasbi alSiddiqi", Jurnal Ilmu-ilmu Keislaman, Afakaruna, Vol. 9, No. 1 Januari-Juni $2013,38$.

TAJDID Vol. 18, No. 1, Januari - Juni 2019 | 107 
diberikan terhadap beragai karya tafsir yang telah ada, sebagai bagian dari kekayaan khazanah intelektual di Indonesia.

Sejarah menunjukkan bahwa penulisan tafsir al-Qur'an di Nusantara telah dimulai sejak abad ke-16, hal ini dibuktikan dari ditemukannya sebuah kitab Tafsir yaitu tafsir Surah al-Kahfi ayat 9 yang telah ditulis pada masa itu di Aceh. Kemudian satu abad berikutnya didapati pula sebuah magnum opus tafsir yang lengkap sebanyak $30 \mathrm{Juz}$, sehingga karya ini ditasbihkan sebagai sebagai kitab tafsir pertama, mengingat sebelumnya belum ada yang mampu menulis kitab tafsir lengkap 30 juz.

\section{Konteks Sosial-Budaya Kajian Tafsir di Indonesia}

Sebuah bidang ilmu tidak akan dapat dipahami ataupun terpahami dengan baik tanpa upaya untuk memahami kondisi atau konteks sosial-budaya yang melatarbelakngi lahirnya sebuah disiplin ilmu, sehingga pemahaman terhadap konteks sosial budaya sebuah disiplin ilmu perlu ditempatkan dalam barisan awal dalam pemahaman sebuah disiplin ilmu. ${ }^{4}$

Berbicara tentang konteks sosial-budaya kajian tafsir di Indonesia, seseorang pengkaji tidak dapat mengabaikan begitu saja terhadap adanya keragaman sosial-budaya yang melingkupi kehidupan umat Islam di Indonesia. Sebagaimana diketahui bahwa sejarah tafsir di Indonsia dikatakan oleh Islah Gusmian telah berlangsung sejak masa 'Abd ar-Rauf as-Sinkīī (1615-1693 M) pada abad ke-17 M hingga masa M. Quraish Shihab pada era awal abad ke-21 M. Dalam rentang waktu tersebutlah (empat anad) berbagai karya-karya tafsir al-Qur'an Indonesia lahir dan berkembang dari tangan-tangan para intelektual Muslim yang handal dalam berbagai latar belakang sosial, budaya dan pendidikan. Mereka juga merupakan para ulama, intelektual, cendikiawan, alaim, ulama yang

${ }^{4}$ Untuk hal ini lihat karya Jerome R. Rovertz, The Philosophy of Science, (Oxford: Oxford University Press, 1982), 192. 
memainkan peran sosial yang beragam, baik sebagai penasihat pemerintah (mufti), tuan guru, kiai di pondok pesantren atau madrasah, muballiqh dan lain sebagainya. Peran-peran yang beragam ini kemudian dibingkai beragam budaya yang turut menyumbangkan corak tafsir dalam kehidupan intelektual masingmasing mufassir. ${ }^{5}$

Dilihat dari latar belakang sosial dan budayanya, tafsir di Indonesia dapat dibagi dalam beberapa corak penafsiran, yaitu: (1) Tafsir yang ditulis dalam pengaruh politik kekuasaan (negara) yang kental; (2) Tafsir yang disusun dalam lingkungan sosial kultural di pondok pesantren; (3) Tafsir yang ditulis ketika penulisnya aktif di lembaga pendidikan formal; (4) Tafsir yang ditulis dalam koteks sosial budaya pada organisasi kemasyarakat (Ormas) Islam; (5) Tafsir yang ditulis di luas latar belakang sosial tertentu. ${ }^{6}$

Pertama, tafsir yang ditulis dalam pengaruh politik kekuasaan (negara) yang kental. Salah satu bentuk tafsir yang dipengaruhi oleh kekuatan politik kekuasaan negara ini adalah tafsir yang ditulis oleh 'Abd ar-Rauf as-Sinkilit, berjudul Tarjumān al-Mustafid. Tafisr ini merupakan karya tafsir al-Qur'an pertama di Nusantara, yang ditulis pada tahun 1675 oleh sang penasehat Kerajaan Aceh dalam enam periode dari tahun 1607- 1688. ${ }^{7}$ Dalam konteks ini jelas terlihat bahwa proses penulisan tafsir ini diwarnai oleh latar sosial-budaya yang dipengaruhi oleh suatu kultur kekuasaan tertentu, yakni Kerajaan Aceh.

Contoh lain karya tafsir yang dipengaruhi oleh kultur kuasa tertentu adalah karya Raden Muhammad Qamar berjudul Tafsir alQur'an al-'Azim. Penulis juga dikenal sebagai Raden Pengulu Tafsir Anom V atau juga dikenal sebagai Pengulu Ageng ke-18 pada

${ }^{5}$ Lihat Islah Gusmian, "tafsir al-Qur'an di Indonesia: Sejarah dan Dinamika", Jurnal Nun, Vol. 1, No. 1, 2015, 4.

${ }^{6}$ Lihat Gusmian, "tafsir al-Qur'an di Indonesia”, 5-15.

${ }^{7}$ Lihat Gusmian, “tafsir al-Qur'an di Indonesia”, 5-6.

TAJDID Vol. 18, No. 1, Januari - Juni 2019 | 109 
Dinasti Kartasura, yang lahir pada tahun 1854 M di Kompleks Pengulon, Surakarta Hadiningrat sebagai anak ke 6 dari Penghulu Tafsir Anom IV, yang garis keturuannya bersambung hingga ke Sultan Trenggana, penguasa terakir Kerajaan Islam Demak. Penulis tafsir ini merupakan Penghulu yang diangkat saat berusia 30 tahun (1815) oleh Sri Susuhunan Pakubuwana IX. ${ }^{8}$ Sehingga tafsir yang ia tulis dapat dikatakan berada dalam konteks sosial-budaya kuasa tertentu.

Corak tafsir yang dipengaruhi oleh pengaruh kekuasaan politik sebenarnya tidak hanya ada dalam tafsir Indonesia "klasik" namun juga ada dalam konteks tafsir Indonesia modern. Tafsir al-Misbah karya M. Quraish Shihab sesungguhnya juga dapat dikategorikan sebagai tafsir yang terpengaruh oleh sosial-budaya kekuasaan Republik Indonesia, mengingat bahwa tafsir ini disusun saat penulis menjabat sebagai Duta Besar Indonesia di Mesir. Dengan demikian dapat dikatakan bahwa tafsir yang ditulis oleh M. Quraish Shihab juga memilki keterlibatan dengan iklim sosial-budaya Pemerintahan Indonesia yang melingkupinya.

Kedua, tafsir yang disusun dalam lingkungan sosial kultural di pondok pesantren, contoh dari tafsir jenis ini adalah tafsir yang ditulis oleh Kyai Imam Ghazali, Guru Pondok Pesantren Mamba' al-'Ulum, Solo, yang berjudul Tafsir al-Balagh. Tafsir yang terbit tahun 1938 oleh Penerbit Toko Buku al-Makmuriyah, Sorosejan. ${ }^{10}$ Selain tafsir ini terdapat pula beberapa kitab tafsir yang ditulis beberapa kalangan Kyai di lingkungan pesantren di antaranya dapat disebutkan: Raudat al-Irfän fì ma'rifah al-Qur'ān dan Tamsyiyatul Muslimin fì Tafsì Kaläm Rabb al-'̄lamin yang merupakan karya dari

${ }^{8}$ Abdul Basith Adnan, K.H.R. Muhammad Adnan: untuk Islam dan Indonesia (Surakarta: Yayasan Mardikintaka, 2003), 13.

${ }^{9}$ Lihat M. Qurais Shihab, Tafsir al-Misbah, Jakarta: Lentera Hati, 2000).

${ }^{10}$ Gusmian, "tafsir al-Qur'an di Indonesia”, 6.

110 | TAJDID Vol. 18, No. 1, Januari - Juni 2019 
KH. Ahmad Sanoesi (1888-1950 M.), al-Ibriz li Márifati Tafsir alQur'ān al-Ariz (1960) yang merupakan karya dari K.H. Bisri Mustofa (1915-1977), Iklīl fì Ma'áni at-Tanzīl (1980) dan Täj alMuslimin du kitab yang menjadi karya dari K.H. Misbah ibn Zainul Mustofa(1916-1994), dan akhirnya Jämi' al-Bayān karya tafsir dari KH. Muhammad bin Sulaiman. ${ }^{11}$

Selain kitab Tafsir yang beredar di Pulau Jawa di atas terdapat karya tafsir di kalangan Pondok Pesanteran yang ada di Sulawesi, di antaranya karya, "Anre Gurutta” H.M. As'ad (w. 1952) seorang Kyai pada Pondok Pesantren di Makasar yang menulis Tafsir Bahasa Boegisnja Soerah Amma, di mana judulnya sengaja ditulis dalam tiga bahasa: Arab, Bugis, dan Indonesia. Untuk edisi bahasa Indonesia dialihbahasakan dan diterbitkan di Sengkang oleh salah seorang muridnya yang beranama Sjamsoeddin, walaupun tidak diketahui pasti tahun terbitnya. ${ }^{12}$

Ketiga, Tafsir yang ditulis ketika penulisnya aktif di lembaga pendidikan formal. Di antara contoh dari pola tafsir ini adalah karya KH. Hamzah Manguluang, seorang ustaz pada Madrasah Aa'adiyah di Sengkang, Kab. Wajo. Ia telah menyelasaikan terjemah al-Qur'an dalam bahasa Bugis 30 Juz yang dibaginya dalam tiga jilid. Dalam penulisanya, penulis membagi tafsirnya dalam dua format, sebelah kiri adalah ayat-ayat al-Qur'an, sementara di sebelah kanan berisi terjemahan ayat dalam bahasa Bugis. Adapun penjelasan diberikan pada ayat tertentu secara singkat. Karya ini telah mendapatkan pengakuan dari sang pemberi kata pengantar yaitu Anre Gurutta H. Daus Isma'il, yang menyatakan bahwa penulis telah mendapatkan

${ }^{11}$ Lihat Gusmian, "tafsir al-Qur'an di Indonesia”, 7.

12Lihat M. Rafii Yunus Martan, "Membidik Universalitas, Mengusung Lokalitas: Tafsir al-Qur'an Bahasa Bugis Karya AG. H. Daud Isma'il" dalam Jurnal Studi al-Qur'an , Vol. 1, No. 3, Tahun 2006, 522.

TAJDID Vol. 18, No. 1, Januari - Juni 2019 | 111 
kemuliaan karena telah menulis tafsir dalam Bahasa Bugis $30 \mathrm{Juz}$ yang belum permah dilakukan sispapun sebelumnya. ${ }^{13}$

Keempat, tafsir yang ditulis dalam koteks sosial budaya pada organisasi kemasyarakat (Ormas) Islam. Salah satu contoh dari tafsir ini adalah tafsir al-Qur'an yang ditulis oleh momunitas Muhammdiyah dengan judul Kur'an Jawen, yaitu tafsir al-Qur'an yang ditulis dalam bahasa Jawa, tafsir ini diterbitkan tahun 1927 oleh Ormas Muhammdiyah bidang Taman Pustaka di Surakarta. ${ }^{14}$ Selain Muhammadiyah, Persis (Persatuan Islam) juga pernah menerbitkan Tafsir al-Furqan, pada tahun 1928. Tafsir ini sendiri ditulis oleh sorang aktivis Persis yang bernama A. Hassan (1887-1958). Tafsir ini karena beberapa hal baru diselesaikan secara utuh tahun 1956 dan dkterbitkan di Surabaya oleh Sa'ad Nabhan. ${ }^{15}$

Kelima, Tafsir yang ditulis di luas latar belakang sosial tertentu. Tafsr ini merupakan tafsir yang memiliki basis sosial-budaya di luar yang empat di atas, sehingga pola tafsir berada dalam konteks sosialbudaya yang cukup independent, bebas dai ikatan identitas dan kepentingan tertentu. Contoh uatama dari corak ataupun pula tafsir ini adalah tafsir yang ditulis oleh Buya Hamka (Haji Abdul Malik Amullah), yang berjudul Tafsir al-Az̧ar. Walaupunjo Buya Hamka masuk dalam Ormas Mjhammadiyah, namun pola tafsirnya cenderung lepas dari pengaruh Ormas tersebut karena ketokohannya yang begitu menonjol. Selain tafsir Buya Hamka tafsir yang ditulis oleh M. uraish Shihab pada beberapa sisi sebenarnya juga dapat dikategorikan dalam corak tafsir ini,

${ }^{13}$ Lihat Islah Gusmian, "Bahasa dan Aksara Tafsir Al-Qur'an di Indonesia: dari Tradisi, Hierarki

hingga Kepentingan Pembaca" dalam Tsaqafah Jurnal Peradaban Islam, Vol. 6, No. 1, April

2010.

${ }^{14}$ Lihat Gusmian, "tafsir al-Qur'an di Indonesia", 15.

${ }^{15}$ A. Hassan, Tafsir al-Furqan, (Surabaya: Salim Nabhan, 1996). 
demikian pula tafsirnya yang berserakan yang ditulis oleh Jalauddin Rakhmat, ataupun M. Dawan Raharjo. ${ }^{16}$

Konteks soslal-budaya di atas menjadi penting untuk memahami sejarah tafsir di Indonesia, mengingat bahwa karya tafsir al-Qur'an akan senantiasa merupakan sebuah produk sosial-budaya tertentu yang dihasilkan dalam pergumulan konteks historis tertentu, ia tidak terlahir dalam ruang hampa yang bersifat a-historis. Ketika konteks sosual-buadaya dapat didudukkan barulah selanjutnya pengembaraan terhadap sejarah tafsir di Indonesia dapat dilakukan.

\section{Embrio Tafsir al-Qur'an dalam Sejarah Islam di Nusantara}

Telah dimafhumi bersama bahwa sejarah penyebaran Islam di Indonesia hingga dewasa ini diyakini tidak lepas dari sumber inti ajaran agama Islam, yaitu al-Qur'an, sehingga tidak masalah jika dikatakan bahwa sejarah perkembangan sejarah Islam di Indonesia sejalan dengan sejarah al-Qur'an dan penafsirannya. Sejarah alQur'an dalam hal ini dikatakan oleh Ahmad Atabik lebih menitikberatkan pada peninggalan-peninggalan tertulis yang lahir dari tradisi intelektual para ulama. Hal in sejalan dengan sejarah tafsir al-Qur'an yang berkonsentgrasi pada pembahasan tentang perkembangan tafsir al-Qur'an yang menitik beratkan pada hasil tafsir berupa kitab-kitab tafsir yang dihasilkan dalam rentetan sejarah. ${ }^{17}$

Berkenaan dengan awal mula masuknya Islam di Nusantara, para peneliti mengungkapkan dua teori besar yang populer untuk menerangkannya, yaitu teori Timur dan teori Barat. Pertama, Teori Timur, yang menerangkan bahwa Islam masuk di Indonesia pada

${ }^{16}$ Lihat Gusmian, “tafsir al-Qur'an di Indonesia”, 16.

${ }^{17}$ Lihat Ahmad Atabik, "Perkembangan Tafsir Modern di Indonesia”, Hermeneutik, Vol. 8, No. 2, Desember 2014, 313.

TAJDID Vol. 18, No. 1, Januari - Juni 2019 | 113 
abad VII M. atau yang menyatakan bahwa Islam di Njusantara disebarkan langsung melalui jalur perdagangan oleh orang-orang Arab yang bermazhab Syafi'i di daerah sepanjang pesisir (coast) pantai utara Sumatera (Malaka); Kedua, teori Barat yang merupakan teori yang bersumber dari perjalanan Marcopolo (1292). Teori ini diperkuat lagi oleh keterangan atau catatan yang dilansir oleh Ibnu Bathuthah yang menjelaskan bahwa berdirinya kerajaan Islam di pantai utara Sumatera pada abad ke- 13. Dalam teori ini dinyatakan bahwa Islam di Nusantara masuk pertama kali di Samudra Pasai, Aceh pada tahun $1290 .{ }^{18}$

Sejak saat itu di Samudra Pasai mulai tumbuh tempat-tempat pendidikan Islam, berupa Surau yang didirikan oleh para ualam Aceh seperti Teungku Cot Mamplam, Teungku di Geureudog dan para ulama lainnya. Al-hasil, pada masa Iskandar Muda, surau-surau di Aceh mengalami masa keemasannya, yang kemudian menghasilkan para ulama terkenal seperti Nuruddin al-Raniri, Ahmad Khatib Langin, Syamsuddin al-Sumatrani, Hamzah Fansuri, Abd. al-Rauf al-Sinkili dan ulama-ulama lainnya. ${ }^{19}$ Pada saat itu pula pengajaran al-Qur'an mengalami kemajuan, hal inilah kemudian yang menjadi embrio lahirnya kitab-kitab Tafsir di Nusantara.

Merujuk pada catatan naskah-naskah klasik yang ditulis oleh para ulama Aceh terdahulu dapat dinilai bahwa pada abad ke-16 telah ada upaya untuk menulis tafsir al-Qur'an di Nusantara. Naskah tafsir QS. al-Kahfi, ayat 9, karya anonomous yang tidak diketahui penulisnya, diperkirakan telah ditulis pada masa awal pemerintahan sultan Iskandar Muda (1607-1636), di mana mufti kesultanannya adalah Syams ad-Din as-Sumatrani, atau bahkan sebelumnya, Sultan 'Ala' ad-Din Ri'ayat Syah Sayyid al-Mukammil

${ }^{18}$ Lihat Muhammad Yunus, Sejarah Pendidikan Islam, Jakarta: Hidakarya Agung, 1984), 24.

${ }^{19}$ M. Nurdin Zuhdi, Pasaraya tafsir Indonesia: dari Kontestasi Metodologi bingga Kontekstualisasi, (Yogyakarta: Kaukaba Dipantara, 2014), 46. 
(1537-1604), di mana mufti kesultanannya adalah Hamzah alFansuri. Di wilayah Sumatera lain, satu abad kemudian juga muncul karya tafsir lengkap 30 juz dengan judul Tarjuman al-Mustafid yang merupakan karya Abd. Rauf asSingkili (1615-1693 M). ${ }^{20}$

Sebagaimana diketahu bahwa ada juga yang menyatakan tradisi Islam di bawa dari Timur Tengah dalam pengaruh sufisme yang kental, karena itu tradisi tafsir di Nusantara sebenarnya juga berkelindan dengan tradisi sufisme di Nusantara. Para sufi ketika mengajar para muridnya tidak jarang mengutif ayat-ayat al-Qur'an yang kemudia tafsirkan dalam konteks mistisisme. Hal inilah misalnya yang dilakukan oleh Hamzah Fansuri dan juga syamsuddin al-Sumatrani. Tidak mengherankan kemudian ada yang menduga bahwa pada masa keduanya telah ada tafsir sederhana yang dihasilkan sebagaimana dugaan para tokoh di atas. ${ }^{21}$

Berbeda halnya di tanah Sumatera, di kepulauan Jawa, penyebaran Islam dilakukan oleh Walisongo. Namun seperti halnya d tanah Sumatera penyebaran Islam di tanah Jawa ini juga tidak lepas kaitannya dengan pengajaran al-Qur'an. Di mulai oleh Raden Rahmad (Sunan Ampel) yang mengajarkan al-Qur'an di pesantrennya di daerah Ampel Denta. Sama persis dengan daerah di Sumatera, di Jawa pengajaran al-Qur'an juga diadakan di surau, yang juga meliputi nama-nama lainnya seperti langgar, mushalla, masjid, atau juga di kediaman sang guru. Proses islamisasi yang dimotori oleh Walisongo ini terjadi seiring dengan berdirinya kerajaan Demak, sekitar tahun 1500. Pada awalnya pengajaran alQur'an dilakukan secara sederhana, namun kemudian saat

${ }^{20}$ Lihat dalam P. Riddel, Transfering a Tradition: 'Abd al-Ra'uf alSingkili's Readering of the Jalalain Commentary, (Berkeley: Centers for South and Southest Asia Studies, No. 31, 1990). Bandingkan dengan Azyumardi Azra, Jaringan Ulama Timur Tengah dan Kepulauan Nusantara Abd XVII dan XVIII: Akar Pembaharuan Islam Indonesia, (Jakarta: Kencana, 2004), 203.

${ }^{21}$ Azra, Jaringan ulama..., 202. 
kesultanan Mataram Islam, terlihat bahwa al-Qur;'an telah memainkan peran penting dalam konstruksi wacana keagamaan seperti terlihat dalam Suluk Sunan Bonang, Suluk Kalijaga, dan Suluk Syaikh Siti Jenar. ${ }^{22}$

Perkembangan selanjutnya menunjukkan bahwa pengajaran alQur;an di tanah Jawa semakin berkembang, bahkan pada tahun 1847, telah muncul istilah nggon ngaji (tempat belajar murid mempelajari al-Qur'an) di seantero Jawa. Di nggon ngaji inilah generasi muda Islam ditempat dalam ilmu al-Qur'an. Hal ini semakin berkembang ketika muncul Pondok-pondok pesantren di tanah Jawa, yang secara meyakinkan telah berhasil melembagakan pendidikan al-Qur'an dan Islam secara luar biasa. Al-hasil selain melakukan kajian tafsir kelasik (terutama tafsir Jalalain), lahirlah beberapa kitab tafsir dari tradisi sosial budaya di Pondok pesantren ini. ${ }^{23}$

\section{Perkembangan Tafsir di Indonesia}

Sebagaimana perjalanan sejarah peradaban Islam yang dibagi dalam beberapa periode mulai dari periode klasik, abad pertengahan, hingga modern, seperti yang diperlihatkan dalam beberapa buku sejarah peradaban Islam karya intelektual "Islam" dan non Islam sekelas Ahmad Amin, A. Shalabi, Montgomery Watt, Philip K. Hitti, Ira Lapidus, hingga karya Buya Hamka dan Badri Yatim di Indonesia. Perkembangan tafsir di Indonesia juga di bagi oleh beberapa peneliti dalam tiga periode besar, yaitu, periode klasik, modern, dan kontemporer. Periode klasik diawali sejak awal abad ke-17 hingga akhir abad ke19; periode modern diawali sejak peruh pertama atau pertengahan abad ke-20 hingga akhir tahun

22Lihat Islah Gusmian, Khazanah Tafsir Indonesia: dari Hermeneutik bingga Ideologi, (Yogyakarta: LkiS, 2013), 22.

${ }^{23}$ Lihat Atabik, "Perkembangan Tafsir Modern di Indonesia", 317

116 | TAJDID Vol. 18, No. 1, Januari - Juni 2019 
1980-an, dan periode kontemporer terjadi sejak awal tahun 1990-an hingga sekarang. ${ }^{24}$

Periode klasik dapat dlihat sebagaimana pembahasan terdahulu merupakan tahap embriotik perkembangan tafsir di Nusantara yang muncul dalam upaya memahami pesan-pesan al-Qur'an dengan menggunakan bahasa Indonesia (Melayu) dan bahasa daerah, sehingga dapat dipahami oleh pembacanya sesuai dengan konteks sosial budaya tertentu. Kenyataan ini telah dimulai sejak awal Islam masuk di Indonesia, yaitu sebelum pondok-pondok pesantren berdiri. Dalam hal ini harus diakui bahwa baru sedikit sekali kajian tafsir al-Qur'an yang dilakukan pada masa itu dibukukan dalam tafsir tersendiri, sehingga dapat dikatakan bahwa Kajian tafsirnya belum bersifat holistik dan masih bercampur baur dengan berbagai ajaran Islam lainnya, seperti ajaran-ajaran tauhid, fiqh, tasawuf, dan dan lain-lain. Kesemuanya juga disajikan dalam konteks amaliyah harian. $^{25}$

Sejarah menunjukkan bahwa penulisan tafsir al-Qur'an di Nusantara telah dimulai sejak abad ke-16, hal ini dibuktikan dari ditemukannya sebuah kitab Tafsir yaitu tafsir Surah al-Kahfi ayat 9 yang telah ditulis pada masa itu di Aceh. Kemudian satu abad berikutnya didapati pula sebuah magnum opus tafsir yang lengkap sebanyak 30 Juz, sehingga karya ini ditasbihkan sebagai sebagai kitab tafsir pertama, mengingat sebelumnya belum ada yang mampu menulis kitab tafsir lengkap 30 juz. Karya tafsir ini dinamakan Tarjuman al-Qur'an, ${ }^{26}$ buah karya dari Abdur Rauf Singkili yang

${ }^{24}$ Tentang periodesasi sejarah tafsir di Indonesia, lihat karya Cucu Surahman, "Pergeseran Pemikiran Tafsir di Indonesia: sebuah Kajian Bibliografis", Jurnal Ilmu-ilmu Keislaman Afkaruna, Vol. 10, No. 2 JuliDesember 2014, 218.

${ }^{25}$ Lihat Indal Abror, "Potret Kronologid Tafsir Indonesia", Vol. 3, No. 2, Juli-Desember 2002, 191.

${ }^{26}$ Zuhdi, "Pasaraya Tafsir Indoensia...", 61. 
selama beberapa abad merajai kitab tafsir di Nusantara, karena ia meruapakan kitab tafsir pertama yang memberikan pengaruih signifikan terhadap kita tafsir berikutnya.

Selanjutnya muncul pula kitab tafsir yang berjudul Faräid alQur'an yang menggunakan bahasa Melayu dan Jawa, mengingat kedua bahasa meruapakan bahasa induk yang digunakan umumnya di Nusantara ketika itu. Dua bahasa ini biasa digunakan sebagai bahasa pemerintahan, hubungan antar bangsa serta dalam hubungan perdagangan. Kitab ini sendiri sesungguhnya masih sangat sederhana dan lebih mirif sebagai artikel tafsir ketimbang kitab tafsir yang sesungguhnya. Ia hanya terdiri dari dua halaman dengan huruf kecil dan spasi rangkap, sehingga ia dimasukkan dalam sebuah buku bunga rampai yang ditulis oleh beberapa ulama Aceh dengan judul Jami' al-Jawami' al-Munsannafät, yang diedit oleh Isma'il bin Abd al-Mutholib al-'Asyi. ${ }^{27}$

Gambaran d atas memperlihatkan bahwa kitab tafsir dalam periode klasik awal bukanlah sebuah karya tafsir yang utuh, di mana karya tafsir yang utuh di Indonesia baru muncul saat memasuki abad ke-19. Di antaranya karya ulama Syafi'iyah Syekh Imam Muhammad Nawawi al-Bantani (w. 1813-1879) yang berjudul Tafsir Munir li Ma'älim al-Tanzìl. Kitaf tafsir ini menggunakan bahasa Arab dan ditulis juga di Arab Saudi dan diselesaikan pada tahun $1305 \mathrm{H}$. Sebelum diterbitkan naskah tafsir ini diperlihatkan kepada para ulama di Mekkah dan Madinah, baru kemudian dicetak di Arab Saudi, hingga mendapatkan pengakuan dari ulama Mesir yang kemudian memberikan gelar kepada Imam Nawawi dengan "Sayyid Ulama' Hijaz”, karena keluasan dan kedalaman pengetahuan yang dimiliki. $^{28}$

Pada periode modern yang diawali sejak peruh pertama atau pertengahan abad ke-20 hingga akhir tahun 1980-an. Karya tafsir

${ }^{27}$ Lihat Gusmian, Khazanah Tafsir Indonesia, 42.

${ }^{28}$ Gusmian, Khazanah Tafsir Indonesia, 43. 
pada periode ini telah diklasifikasi oleh Howard M. Federspiel dalam karnya Popular Indonesian Literature of the Qur'an, yang mengklasifikasi 58 Kitab tafsir yang terbit dalam kurun waktu modern, yaitu antara tahun 1950-an hingga 1980-an. Di antaranya adalah karya Mahmud Yunus, Tafsir al-Qur'an al-Karim (1973); karya Ormas Persis yang berjudul Tafsir al-Hidayah (dikerjakan selama kurun 1935-1940); karya Buya Hamka (w. 1981) yang berjudul Tafsir al-Az̧har; dua karya T.M. Hasbi ash-Shiddieqy (w. 1975), yang berjudul Tafsir al-Qur'an al-Madjid dan Tafsir al-Bayan; serta karya Oemar Bakry yang berjudul Tafsir Rabmat. ${ }^{29}$

Tafsir pada periode modern ini telah dikategorisasi oleh Howard M. Federspiel dalam menjadi tiga generasi yang masingmasing memiliki kekhasannya tersendiri, yaitu: Generasi pertama, ditandai dengan upaya penerjemahan atau tafsir yang dilakukan secara terpisah-pisah, yang dimulai dari permulaan abad ke-20 hingga tahun ke 60-an; Generasi kedua, merupakan generasi follow up yaitu generasi yang mengikuti generasi pertama dan bertindak sebagai generasi yang menyempurnakan apa yang telah dilalukan oleh generasi pertama, terutama dalam bidang metodologi tafsir. Karya-karya tafsir yang termasuk generasi kedua ini menurut Federspiel muncul pada tahun 60-an yang dicirikan dengan adanya catatan khusus, catatan kaki, atau bahkan disertai dengan kelengkapan indeks yang dilakukan secara sederhana. Contoh dari tafsir generasi kedua ini antara lain Tafsir al-Furqan karya A Hassan tahun 1928, Tafsir al-Qur'an al-Karim atau Tafsir al-Qur'an Indonesia, buah karya dari Mahmud Yunus pada tahun 1935, serta Tafsir alQur'an karya Zainuddin Hamidi dan Fachruddin yang diterbitkan tahun 1959; Generasi ketiga, merupakan generadi yang berhasil menafsirkan al-Qur'an secara lengkap yang muncul pada tahun 1970-an. Karya tafsir pada generasi ini biasanya telah dilengkapi dengan pengantar metodologi, indeks yang lengkap hingga dapat

${ }^{29}$ Surahman, "Pergeseran Pemikiran Tafsir di Indonesia", 219.

TAJDID Vol. 18, No. 1, Januari - Juni 2019 | 119 
memperlihatkan wawasan yang luas masig-masing penulis. Di antara contoh tafsir generasi ini adalah Tafsir al-Nur/ al-Bayan karya TM. Hasbi ash-Shiddieqi yang terbit tahun 1966, karya Buya Hamka tahun 1973 yaitu Tafsir al-Azhar, serta Tafsir al-Qur'an alKarim karya Halim Hasan dan kawan-kawan, yang terbit tahun 1955..$^{30}$

Periode modern ini ditandai pula oleh munculnya karya yang membahas tentang ilmu dan metode tafsir, seperti karya Hasbi ashShiddieqy tentang "Sejarah dan Pengantar Ilmu Tafsir" (1952) atau karya Masyfuk Zuhzi, Pengantar 'Ulumul Qur'an' (1979). Selain itu pada periode ini juga mulai muncul gelombang pemikiran yang menyerukan tentang pentingnya pembaruan pemikiran Islam, yang diantaranya dipelopori oleh para sarjanawan Islam yang telah kembai dari pendidikannya di Timur Tengah ataupun Barat, seperti figur Nurcholish Madjid (w. 2005), Harun Nasution (w. 1998), Kuntowijoyo (w.2007), ataupun Jalaluddin Rahmat. ${ }^{31}$ Mdereka adalah figur yang berupaya melakukan penyegaran pemikiran Islam terutama lewat perubahan pola pikir dalam penfsiran Islam yang tidak semata bersifat tekstual namun juga kontekstual.

Akhirnya periode kontemporer yang terjadi sejak awal tahun 1990-an hingga sekarang. Beberapa karya tafsir pada periode ini dapat dilihat dalam karya Islah Gusmian yang berjudul Khazanah Tafsir Indonesia: dari Hermeneutika hingga Ideologi. ${ }^{32} \mathrm{Di}$ antara karya tafsir yang masuk periode ini adalah karya Jalaluddin Rahmat, yang berjudul Konsep Perbuatan Manusia menurut al-Qur'an: suatu Kajian Tematik (1992); ${ }^{33}$ Karya Tim UII Yogyakarta yang berjudul al-Qur'an

30Lihat Atabik, "Perkembangan Tafsir Modern di Indonesia", 320.

${ }^{31}$ Surahman, "Pergeseran Pemikiran Tafsir di Indonesia", 219.

${ }^{32}$ Lihat Gusmian, Khazanah Tafsir Indonesia.

${ }^{33}$ Lihat Jalaluddin Rahmat, Konsep Perbuatan Manusia menurut al-Qur'an: suatu Kajian Tematik, (Jakarta: Bulan Bintang 1992). 
dan Tafsimya (1995); $;^{34}$ karya M. Qurais Shihab yang berjudul Wawasan al-Qur'an: Tafsir Maudhu'i atas Pelbagai Persoalan Umat (1996); ${ }^{35}$ karya Nasaruddin Umar, Argumen Kesetaraan Jender: Perspektif al-Qur'an (1999); ${ }^{36}$ karya karya Achmad Mubarok, Jiwa dalam al-Qur'an: Solusi Sosial Krisis Kerubanian Manusia Modern (2000); ${ }^{37}$ hingga tafsir karya M. Quraish Shihab, yang berjudul Tafsir al-Mishbah: Pesan, Kesan, dan Keserasian al-Qur'an (2000). ${ }^{38}$

Karya-karya di atas hanya sebagian dari beberapa tafsir yang muncul pada periode kontemporer. Selain karya tafsir di atas pada periode kontemporer ini muncul juga karya yang mambahas tentang metode dan pendekatan dalam menafsirkan al-Qu'an yang kesemuanya memberikan sumbangan bagi kekayaan kahazanah kajian tafsir di Indonesia.

\section{Penutup}

Kajian di atas memberikan sebuah pemahaman bahwa tafsir yang ada di Indonesia telah mengalami perkembangan yang cukup panjang mulai dari periode klasik, periode modern hingga periode kontemporer. Di mana masing-masing tafsir yang memang tidak dalam kesempatan ini didalami satu persatu memiliki kekhasan tersendiri, karena ia lahir dan tumbuh dalam sebuah ruang sosial budaya tertentu, hal inilah yang kemudian turut memberikan corak dan pola terhadap tafsir yang dihasilkan. Walaupun demikian

${ }^{34}$ Lihat Tim UII Yogyakarta, al-Qur'an dan Tasirnya, (Yogyakarta: PT. Dana Bhakti Wakaf UII, 1995).

${ }^{35} \mathrm{M}$. Qurais Shihab, Wawasan al-Qur'an: Tafsir Maudhu'i atas Pelbagai Persoalan Umat, (Bandung: Mizan, 1996).

${ }^{36}$ Nasaruddin Umar, Argumen Kesetaraan Jender: Perspektif al-Qur'an, (Jakarta: Paramadina, 1999).

${ }^{37}$ Lihat Achmad Mubarok, Jiwa dalam al-Qur'an: Solusi Sosial Krisis Kerubanian Manusia Modern (Jakarta: Paramadina, 2000)

${ }^{38} \mathrm{M}$. Quraish Shihab, Tafsir al-Mishbah: Pesan, Kesan, dan Keserasian alQur'an, (Jakarta: Lentera Hati, 2000).

TAJDID Vol. 18, No. 1, Januari - Juni 2019 | 121 
sebuah apresiasi besar tetap harus diberikan terhadap beragai karya tafsir yang telah ada, sebagai bagian dari kekayaan khazanah intelektual di Indonesia.

\section{Daftar Pustaka}

Abror, Indal. "Potret Kronologid Tafsir Indonesia". Vol. 3, No. 2, Juli-Desember 2002,

Adnan, Abdul Basith. K.H.R. Muhammad Adnan: untuk Islam dan Indonesia. Surakarta: Yayasan Mardikintaka, 2003.

Amin, Surahman dan Siregar, Ferry Muhammadsyah. "Telaah atas Karya Tafsir di Indonesia: Studi atas Tafsir al-Bayan Karya TM. Hasbi al-Siddiqi". Jurnal Ilmu-ilmu Keislaman, Afakaruna. Vol. 9, No. 1 Januari-Juni 2013.

Atabik, Ahmad. "Perkembangan Tafsir Modern di Indonesia". Hermeneutik. Vol. 8, No. 2, Desember 2014.

Azra, Azyumardi. Jaringan Ulama Timur Tengah dan Kepulauan Nusantara Abd XVII dan XVIII: Akar Pembaharuan Islam Indonesia. Jakarta: Kencana, 2004.

Gusmian, Islah. "Bahasa dan Aksara Tafsir Al-Qur'an di Indonesia: dari Tradisi, Hierarki hingga Kepentingan Pembaca". Tsaqafah Jurnal Peradaban Islam, Vol. 6, No. 1, April 2010.

Gusmian, Islah. “Tafsir al-Qur'an di Indonesia: Sejarah dan Dinamika”. Jurnal Nun. Vol. 1, No. 1, 2015.

Gusmian, Islah. Khazanah Tafsir Indonesia: dari Hermeneutik bingga Ideologi. Yogyakarta: LkiS, 2013.

Hassan, A. Tafsir al-Furqan. Surabaya: Salim Nabhan, 1996.

Iqbal, Muhammad Iqbal. "Contemporary Development of Qur'anic Exegesis in Indonesia and Iran". Jurnal of Contemporary Islam and Muslim Society. Vol. 3, No. 1 Januari-Juni 2019. 
Martan, M. Rafii Yunus. "Membidik Universalitas, Mengusung Lokalitas: Tafsir al-Qur'an Bahasa Bugis Karya AG. H. Daud Isma'il”. Jurnal Studi al-Qur'an. Vol. 1, No. 3, Tahun 2006.

Mubarok, Achmad. Jiwa dalam al-Qur'an: Solusi Sosial Krisis Kerubanian Manusia Modern. Jakarta: Paramadina, 2000.

Rahmat, Jalaluddin. Konsep Perbuatan Manusia menurut al-Qur'an: suatu Kajian Tematik. Jakarta: Bulan Bintang 1992.

Riddel, P. Transfering a Tradition: 'Abd al-Ra'uf al-Singkili's Readering of the Jalalain Commentary. Berkeley: Centers for South and Southest Asia Studies, No. 31, 1990.

Rovertz, Jerome R. The Philosophy of Science. Oxford: Oxford University Press, 1982.

Shihab, M. Qurais. Tafsir al-Misbah. Jakarta: Lentera Hati, 2000.

Shihab, M. Quraish. Tafsir al-Mishbah: Pesan, Kesan, dan Keserasian al-Qur'an. Jakarta: Lentera Hati, 2000.

Shihab, M. Quraish. Wawasan al-Qur'an: Tafsir Maudhu'i atas Pelbagai Persoalan Umat. Bandung: Mizan, 1996.

Surahman, Cucu. "Pergeseran Pemikiran Tafsir di Indonesia: sebuah Kajian Bibliografis". Jurnal Ilmu-ilmu Keislaman Afkaruna, Vol. 10, No. 2 Juli-Desember 2014.

Suyūtī, Abu al-Fadhl Jalāl al-Dīn al-. al-Itqān fi 'Ulüm al-Qur'an. Beirut: Dar al-Kutub al-Ilmiyah, 1991. Vol. 2, Cet. 2.

Tim UII Yogyakarta, al-Qur'an dan Tasirnya, Yogyakarta: PT. Dana Bhakti Wakaf UII, 1995.

Umar, Nasaruddin. Argumen Kesetaraan Jender: Perspektif alQur'an. Jakarta: Paramadina, 1999.

Yunus, Muhammad. Sejarah Pendidikan Islam. Jakarta: Hidakarya Agung, 1984. 
Abdul Latif

Zuhdi, M. Nurdin. Pasaraya tafsir Indonesia: dari Kontestasi Metodologi hingga Kontekstualisasi. Yogyakarta: Kaukaba Dipantara, 2014.

124 | TAJDID Vol. 18, No. 1, Januari - Juni 2019 